\title{
COMPARATIVE STUDY OF TOXICITY OF 4-NITROPHENOL AND 2,4-DINITROPHENOL IN NEWBORN AND YOUNG RATS
}

\author{
Mutsuko KOIZUMI ${ }^{1}$, Yuzuru YAMAMOTO², Yoshihiko ITO², Masao TAKANO $^{3}$, \\ Tomonori ENAMI ${ }^{3}$, Eiichi KAMATA ${ }^{1}$ and Ryuichi HASEGAWA ${ }^{1}$ \\ ${ }^{1}$ Division of Risk Assessment, National Institute of Health Sciences, \\ 1-18-1 Kamiyoga, Setagaya-ku, Tokyo 158-8501, Japan \\ ${ }^{2}$ Research Institute for Animal Science in Biochemistry and Toxicology, \\ 3-7-11 Hashimotodai, Sagamihara-shi, Kanagawa 229-1132, Japan \\ ${ }^{3}$ Gotemba Laboratory, Bozo Research Center Inc., \\ 1284 Kamado, Gotemba-shi, Shizuoka 412-0039, Japan
}

(Received July 13, 2001; Accepted September 3, 2001)

\begin{abstract}
The toxicities of 4-nitrophenol and 2,4-dinitrophenol in newborn and young rats was examined and the susceptibility of newborn rats was analyzed in terms of presumed unequivocally toxic and no observed adverse effect levels (NOAELs). In the 18-day repeated dose newborn rat study, 4-nitrophenol was orally given from Day 4 to Day 21 after birth but did not induce any toxicity up to $160 \mathrm{mg} / \mathrm{kg}$ in the main study, although it induced death in one of six males at $160 \mathrm{mg} / \mathrm{kg}$, and three of six males and one of six females at $230 \mathrm{mg} / \mathrm{kg}$ in a prior dose-finding study. In the 28-day repeated dose oral toxicity study starting at 6 weeks of age, 4-nitrophenol caused the death of most males and females at 1,000 mg/kg but was not toxic at $400 \mathrm{mg} / \mathrm{kg}$ except for male rat-specific renal toxicity. As unequivocally toxic levels were considered to be $230 \mathrm{mg} / \mathrm{kg} / \mathrm{day}$ in newborn rats and 600 to $800 \mathrm{mg} / \mathrm{kg} / \mathrm{day}$ in young rats, and NOAELs were $110 \mathrm{mg} / \mathrm{kg} /$ day in newborn rats and $400 \mathrm{mg} / \mathrm{kg} /$ day in young rats, the susceptibility of the newborn to 4-nitrophenol appears to be 2.5 to 4 times higher than that of young animals. In the newborn rat study of 2,4-dinitrophenol, animals died at $30 \mathrm{mg} / \mathrm{kg}$ in the dose-finding study and significant lowering of body and organ weights was observed at $20 \mathrm{mg} / \mathrm{kg}$ in the main study. In the 28-day young rat study, clear toxic signs followed by death occurred at $80 \mathrm{mg} / \mathrm{kg}$ but there was no definitive toxicity at $20 \mathrm{mg} / \mathrm{kg}$. As unequivocally toxic levels and NOAELs were considered to be 30 and $10 \mathrm{mg} / \mathrm{kg} / \mathrm{day}$ in newborn rats and 80 and $20 \mathrm{mg} / \mathrm{kg} /$ day in young rats, respectively, the toxicity of 2,4-dinitrophenol in newborns again seems to be 2 to 3 times stronger than in young rats. Abnormalities of external development and reflex ontogeny in the newborn were not observed with either chemical. Based on these results, it can be concluded that the toxic response in newborn rats is at most 4 times higher than that in young rats, at least in the cases of 4-nitrophenol and 2,4-dinitrophenol.
\end{abstract}

KEY WORDS: Toxic response in newborn rat, 4-Nitrophenol, 2,4-Dinitrophenol

\section{INTRODUCTION}

Endocrine disrupting chemicals have been demonstrated to induce adverse effects on reproductive organs with in utero (Bullock et al., 1988; Gray et al., 1994, 1997a and 1997b) or perinatal exposure (Gray et al., 1994; Mylchreest et al., 1998). Furthermore, it was shown that postnatal exposure may also exert detrimen- tal influence in both male and female animals. Nonylphenol reduced organ weights of testes, epididymides, seminal vesicles and prostates in male rats at Day 31 when the animals were intraperitoneally injected at more than $0.08 \mathrm{mg} / \mathrm{kg} /$ day during Days 1 to 15 after birth (Lee, 1998). In the worst case, cryptorchidism was observed in 30 to $60 \%$ of male infants at a dose of $8 \mathrm{mg} / \mathrm{kg} /$ day, leading to infertility. p-tert- 
Octylphenol also induced earlier vaginal opening, persistent estrus after sexual maturation and atrophy of ovaries in female rats on subcutaneous administration at $100 \mathrm{mg} / \mathrm{kg}$ every other day during Days 1 to 15 after birth (Katsuda et al., 2000). Diethylstilbestrol depressed spermatogenesis with severe testicular atrophy in hamsters at 90 days of age (adults) when a single injection of $100 \mu \mathrm{g} / \mathrm{animal}$ was given on the day of birth, but the testes had no abnormalities at 42 days of age (pubertal) (Khan et al., 1998).

Based on these available information, it is very important to examine the toxicity profiles and levels of chemicals in newborn to lactating animals and compare them with test results using young animals. As infants developing so quickly might be very strongly affected, safety of chemical exposure is particularly problematic. Unfortunately, there is no standard experimental protocol for infants and the above studies on estrogenic chemicals were conducted only for reproductive organs and functions. Therefore, a new protocol for infant repeated dose toxicity study, described in the "MATERIALS AND METHODS," was established.

In an existing chemical testing program of Japan in 1999, 45 chemicals were selected for an ordinary 28 day repeated dose oral toxicity study because there was no sufficient oral toxicity information of these chemicals for hazard assessment. Among the chemicals, 14 phenolic derivatives were selected to compare toxicological profiles and toxicity levels in newborn and young animals using the same lot number of chemicals, same rat strain and a newly established protocol, considering the potential for estrogenic action in the early development period. In the present study, two nitrophenols, 4-nitrophenol (4NP) and 2,4-dinitrophenol (DNP) were chosen for evaluation as the first trial in our series. Both chemicals were listed in the OECD High Production Volume Chemical Table in 1999, meaning that they are produced at levels greater than 1,000 tonnes per year in at least one OECD member country. 4NP has found use in the production of dyes, pigments, medicines, photographic chemicals and pesticides, but there was insufficient information on oral toxicity except for an unpublished study described in Toxicological Profiles for nitrophenols: 2-nitrophenol and 4nitrophenol (ATSDR, 1991). DNP has been used in the production of black sulfur dye, herbicides, pesticides and wood preservatives. Furthermore, it had been used as diet pills once (ATSDR, 1995) and has been widely employed as an uncoupling agent for oxidative phosphorylation especially for in vitro biochemical purposes. Regarding toxicity, various effects in animals and humans likely due to oxidative phosphorylation uncoupling effects, such as death, hyperthermia, and body weight loss are reported (ATSDR, 1995).

Our 28-day repeated dose oral toxicity studies of these chemicals in young rats have been already published (MHLW, 2001a and 2001b). Under the same experimental condition, we have now examined the toxicity of these chemicals in newborn rats. Based on analysis of both studies including their dose-finding processes, appropriate unequivocally toxic levels, defined in this study as a dose inducing severe toxic signs including death or critical histological damages, and no observed adverse effect levels (NOAELs) for newborn and young rats, were established, and differences in toxicity levels between them were estimated with reference to infant protection from chemical exposure.

\section{MATERIALS AND METHODS}

\section{Materials}

Sodium 4-nitrophenoxide dihydrate (CAS No. 42083-62-5, purity: 98.5\%) for studies on 4-nitrophenol (4NP: CAS No. 100-02-7) was obtained from Mitsui Chemicals Inc. (Tokyo, Japan) and suspended in $0.5 \mathrm{w} / \mathrm{v} \%$ carboxymethylcellulose-Na solution. 2,4Dinitrophenol (CAS No. 51-28-5, purity: $85.2 \%, 13.9$ $\%$ water, $0.6 \%$ 2,6-dinitrophenol and $0.3 \%$ unknown compounds as impurities) was also obtained from Mitsui Chemicals Inc. (Tokyo, Japan) and suspended in $1 \mathrm{w} / \mathrm{v} \%$ methylcellulose solution.

\section{Animals}

Sprague-Dawley SPF rats [Crj:CD(SD)IGS] were purchased from Charles River Japan Inc. (Atsugi, Japan) and maintained in an environmentally controlled room at $23 \pm 3^{\circ} \mathrm{C}$ with a relative humidity of $50 \pm 20 \%$, a ventilation rate of more than 10 times per $\mathrm{hr}$, and a $12: 12 \mathrm{hr}$ light/dark cycle. In the 18-day study of newborn rats, 20 pregnant rats (gestation day 14 15) were purchased and normally delivered. Among all newborn separated from each dam at ages of Days 3, 4 males and 4 females were randomly selected and assigned to 4 dose groups including controls. Twelve foster mothers suckled the 4 males and 4 females assigned to each group up to weaning on Day 21 after birth (termination of dosing). After weaning, the animals of the recoverymaintenance group were individually maintained for 9 weeks. In the 28-day study of young rats, 4 5 week-old male and female rats were obtained and used at ages of 5 6 weeks old after acclimation. All animals were 
Comparative study of toxicity in newborn and young rats.

allowed free access to sterilized basal diet (4NP: CRF1, Oriental Yeast Co. Ltd., Tokyo, Japan, DNP: LABO MR stock, Nihon Nosan Kogyo Inc., Yokohama, Japan) and tap water.

Study design (Time schedule described in Scheme 1) 1. 18-day repeated dose study in newborn rats 1) Dose-finding study

Newborn rats (4NP: 6/sex/dose, DNP: 5/sex/dose) were administered $4 \mathrm{NP}$ at $0,110,160,230$ or 320 $\mathrm{mg} / \mathrm{kg} / \mathrm{day}$, or DNP at $0,3,10$ or $30 \mathrm{mg} / \mathrm{kg} /$ day by gastric intubation from Days 4 to 21 after birth. Rats were examined for general behavior and body weights during the dosing period, and sacrificed at 22 days old after overnight starvation for examination of hematology, blood biochemistry, macro findings and organ weights.

\section{2) Main study}

Newborn rats were administered $4 \mathrm{NP}$ at $0,80,110$ or $160 \mathrm{mg} / \mathrm{kg} / \mathrm{day}$, or DNP at $0,3,10$ or $20 \mathrm{mg} / \mathrm{kg} / \mathrm{day}$ by gastric intubation daily from days 4 to 21 after birth, based on results of the dose-finding study, and sacrificed after overnight starvation following the last treatment. Recovery-maintenance groups at the same dosages were maintained for 9 weeks without chemical treatment and fully examined at 12 weeks old, the same age as at the end of the recovery period of the present 28 -day study of young rats. The number of animals at each sex/dose was 6 for both scheduled-sacrifice and recovery-maintenance.

General behavior was daily observed for newborn rats (separated from each foster mother) and foster mothers. Body weight and food consumption were measured more than once a week (food consumption, after weaning). At treatment Day 17 or 18, pupillary reflex, corneal reflex, surface righting, mid-air righting and auricular reflexes were examined as parameters of reflex ontogeny. Furthermore, fur appearance, incisor eruption and eye opening were noted in the lactating period as evidence of physical development, and preputial separation (4NP) or testes descent (DNP) and vaginal opening during the early recovery-maintenance period for assessment of sexual maturation. Color, $\mathrm{pH}$, occult blood, protein, glucose, ketone bodies, bilirubin, urobilinogen, urine sediment and volume of the urine were examined only at the end of the recovery-maintenance period. For hematology and blood biochemistry, blood was collected from the abdominal aorta under ether anesthesia at sacrifice after overnight starvation for the scheduled-sacrifice and recovery-maintenance groups. One part of the blood was treated with EDTA-

\section{Administration Schedule}

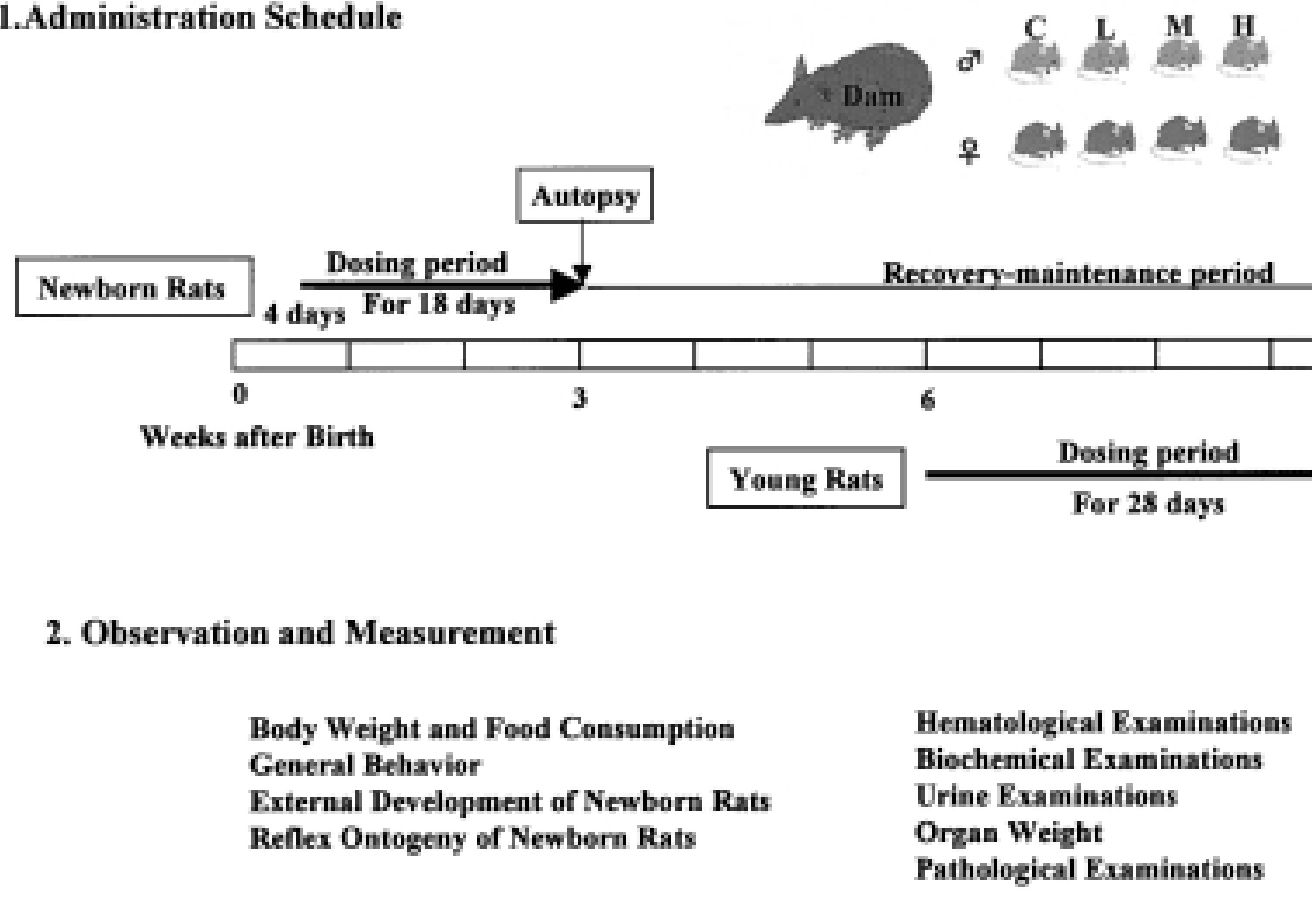

Scheme 1. Experimental Protocol. 
$2 \mathrm{~K}$ or $3.8 \%$ sodium citrate and examined for hematological parameters such as the red blood cell count (RBC), hemoglobin $(\mathrm{Hb})$, hematocrit $(\mathrm{Ht})$, mean corpuscular volume, mean corpuscular hemoglobin, mean corpuscular hemoglobin concentration, white blood cell count, platelet counts, reticulocyte ratio, differential leukocyte count, and blood clotting parameters such as prothrombin time and activated thromboplastin time. Plasma or serum obtained from another portion of the blood was analyzed for blood biochemistry (total protein, albumin, albumin-globulin ratio, glucose, total cholesterol, triglycerides, total bilirubin, urea nitrogen, creatinine, glutamate oxaloacetate transaminase (GOT), glutamate pyruvate transaminase, $\gamma$-glutamyl transpeptidase, lactate dehydrogenase, alkaline phosphatase, calcium, inorganic phosphorus, sodium, potassium, chlorine). After macro findings for all organs of animals sacrificed under ether anesthesia, the brain, pituitary gland, heart, thymus, liver, kidneys, spleen, adrenals, thyroids, lungs, testes, epididymides, prostates (DNP), ovaries and uterus were removed and weighed. The trachea, pancreas, lymphatic glands, stomach, intestine, urinary bladder, spinal cord, sciatic nerve, seminal vesicles and prostates as well as the above organs were fixed with $10 \%$ buffered formalin-phosphate (Bouin's fixation for testes and epididymis) and paraffin sections were routinely prepared and stained with Hematoxylin-Eosin for microscopic examination.

\section{28-day repeated dose study in young rats}

\section{1) Dose-finding study (14 days study)}

Five to six-week old rats (4NP: 5/sex/dose, DNP: $4 / \mathrm{sex} / \mathrm{dose}$ ) were administered $4 \mathrm{NP}$ at $3,12.5,50$ or $200 \mathrm{mg} / \mathrm{kg} / \mathrm{day}$, or DNP at $0,0.6,2,6,20$ or 60 $\mathrm{mg} / \mathrm{kg} /$ day by gastric intubation for 14 days. Rats were examined for general behavior, body weight and food consumption during dosing and sacrificed at Day 15 after overnight starvation for examination of hematology, blood biochemistry, macro findings and organ weights (and urinalysis for DNP).

\section{2) Main study}

Five to six-week old rats were given the test substances by gastric intubation daily for 28 days and sacrificed after overnight starvation following the last treatment. Referring to the results of preliminary studies including the above dose-finding study, 5 doses including the control were established (4NP: 0, 60, $160,400,1,000 \mathrm{mg} / \mathrm{kg} /$ day, DNP: 0, 3, 10, 30, 80 $\mathrm{mg} / \mathrm{kg}$ /day). Recovery groups (4NP: 0, 160, 400, 1,000 $\mathrm{mg} / \mathrm{kg} /$ day, DNP: 0, 30, $80 \mathrm{mg} / \mathrm{kg} /$ day) were main- tained for 2 weeks without chemical treatment and fully examined at 11 to 12 weeks of age. The number of animals for each sex/dose was 6 for both scheduledsacrifice and recovery. Rats were examined for general behavior, body weight, food consumption, urinalysis, hematology and blood biochemistry, necropsy finding, organ weights and histopathological finding in compliance with the Test Guideline of the Japanese Chemical Control Act (Official Name: Law Concerning the Examination and Regulation of Manufacture, etc. of Chemical Substances) under Good Laboratory Practice conditions.

\section{Statistical analysis}

Continuous data were analyzed by Bartlett's test (Bartlett, 1937) for homogeneity of distribution ( $\mathrm{p}<0.01$ or 0.05 ). When homogeneity was recognized, Dunnett's test (Dunnett, 1964) or Scheffe's test (Scheffe, 1953) ( $\mathrm{p}<0.01$ or 0.05$)$ was conducted for group comparison (control vs treatment). If not homogenous, the data were analyzed using the Kruskal-Wallis ranking analysis (Kruskal and Wallis, 1952) $(\mathrm{p}<0.05)$ or the mean rank test of Dunnett type (Hollander and Wolfe, 1973) ( $\mathrm{p}<0.01$ or 0.05 ). Quantitative data for general appearance, functional tests and histopathology were analyzed by MannWhitney's U test (Mann and Whitney, 1947) or Fisher's exact test (Fisher, 1973) $(\mathrm{p}<0.005$ or 0.025$)$.

\section{RESULTS}

\section{4-Nitrophenol}

\section{18-day study in newborn rats (including the dose-finding study)}

In the dose-finding study, 5/6 males and $6 / 6$ females at $320 \mathrm{mg} / \mathrm{kg}, 3 / 6$ males and 1/6 females at 230 $\mathrm{mg} / \mathrm{kg}$, and $1 / 6 \mathrm{males}$ at $160 \mathrm{mg} / \mathrm{kg}$ died during the early dosing period, and most of them exhibited convulsions before death (Table 1). However, no toxic signs or deaths were observed in the main study, even at the highest dose of $160 \mathrm{mg} / \mathrm{kg}$ (data not shown). Body weights demonstrated a few transient changes in the dosing period (Fig. 1) and a tendency for increase in the recovery-maintenance period (data not shown) of males in the main study, not considered due to the chemical treatment. No definitive changes in abdominal fur appearance, incisor eruption, eye opening and preputial separation or vaginal opening as well as reflex ontogeny parameters were detected in any of the dose groups (data not shown). There were also no significant changes in absolute and relative organ weights of the 
Comparative study of toxicity in newborn and young rats.

scheduled-sacrifice and recovery-maintenance groups, except for a slight increase in relative liver weights in $160 \mathrm{mg} / \mathrm{kg}$ males of the scheduled-sacrifice group (Major results are shown in Table 2). No other chemical-related changes were observed for hematology, blood biochemistry, histopathology or urinalysis.

The unequivocally toxic level in newborn rats was concluded to be $230 \mathrm{mg} / \mathrm{kg} /$ day because some animals

Table 1. Clinical signs and mortality in the 18-day dose-finding study of 4-nitrophenol in newborn rats.

\begin{tabular}{lcccc}
\hline & \multicolumn{4}{c}{ Dose $(\mathrm{mg} / \mathrm{kg})$} \\
\cline { 2 - 5 } & 110 & 160 & 230 & 320 \\
\hline Males & & 6 & 6 & 6 \\
$\quad$ No. of animals & 6 & - & 2 & 4 \\
$\quad$-Convulsions & - & 1 & 3 & 5 \\
$\quad$ Death & - & & & \\
Females & & 6 & 6 & 6 \\
$\quad$ No. of animals & 6 & - & 1 & 3 \\
-Convulsions & - & - & 1 & 6 \\
$\quad$ Death & - &
\end{tabular}

$-:$ No animals with the clinical sign.

Convulsions were observed before death during early dosing period.

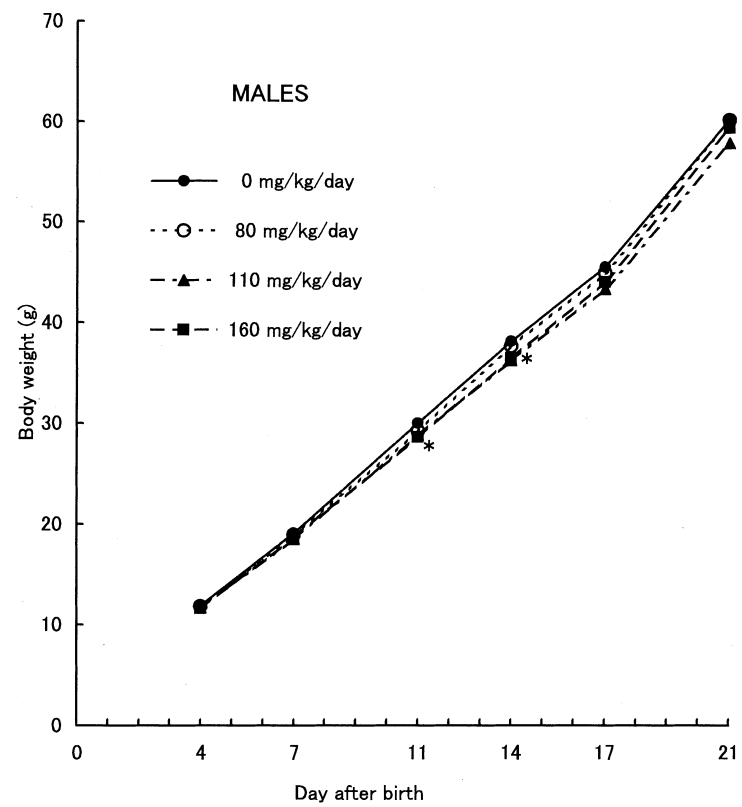

died at this dose in the dose-finding study, but only one of 36 animals in the dose-finding and main studies died at $160 \mathrm{mg} / \mathrm{kg}$. The NOAEL was concluded to be 110 $\mathrm{mg} / \mathrm{kg} / \mathrm{day}$, at which there was no evidence of toxicity in the main study.

\section{28-day study in young rats (including the dose- finding study)}

4NP did not exert any significant toxicity up to $200 \mathrm{mg} / \mathrm{kg}$ in the dose-finding study, the doses being set from an $\mathrm{LD}_{50}$ value of approximate $500 \mathrm{mg} / \mathrm{kg}$ (MHLW, 2001a). At $1,000 \mathrm{mg} / \mathrm{kg}$ in the main study, more than half of the animals died after oligopnea and adoption of a prone/lateral position on the first dosing day, some of them also showing tonic convulsions (Table 3). As 10 of 12 males and females finally died, the surviving animals at this dose were sacrificed at the end of the administration period. The only significant pathological change was a higher incidence of eosinophilic bodies in proximal tubular cells of the kidneys in $400 \mathrm{mg} / \mathrm{kg}$ and $1,000 \mathrm{mg} / \mathrm{kg}$ males, as shown in Table 4. No other chemical-related changes in body weight, food consumption, organ weight, hematology, blood biochemistry and urinalysis were observed in any of the groups including the recovery groups.

As the male rat-specific change in the kidney is considered to be due to ${ }_{2 \mathrm{U}}$-globulin complex forma-

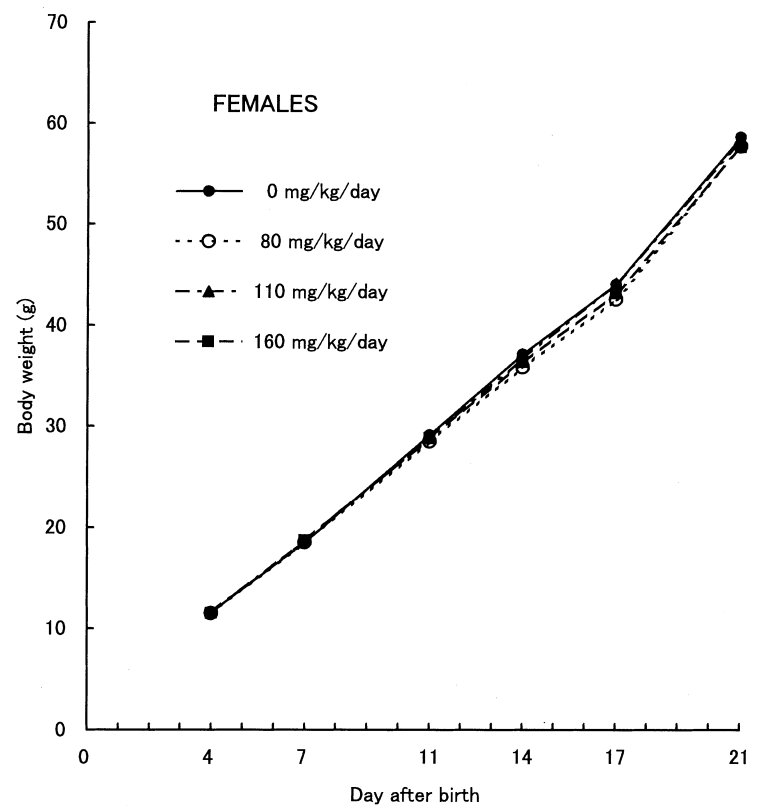

Fig. 1. Body weight change during the dosing period in the 18-day study of 4-nitrophenol in newborn rats. *: Significantly different from the controls $(\mathrm{p}<0.05)$. 
M. KOIZUMI et al.

tion and not relevant to humans, the NOAEL for repeated dose toxicity in young rats was concluded to be $400 \mathrm{mg} / \mathrm{kg} / \mathrm{day}$ for both sexes. It is also speculated that the appropriate unequivocally toxic level might be in the range from 600 to $800 \mathrm{mg} / \mathrm{kg} /$ day because most animals died at $1,000 \mathrm{mg} / \mathrm{kg}$.

\section{2,4-Dinitrophenol}

\section{18-day study in newborn rats (including the dose-finding study)}

No clinical signs or deaths were encountered in the main study, but decrease in locomotor activity and panting were observed in both sexes, and 4/5 males and $1 / 5$ females died at $30 \mathrm{mg} / \mathrm{kg}$ in the dose-finding study (Table 5). The body weights at $20 \mathrm{mg} / \mathrm{kg}$ were significantly below control values from dosing Day 7 in males and dosing Day 10 in females in the scheduledsacrifice group (Fig. 2). There was also statistically significant lowering of body weights in the $20 \mathrm{mg} / \mathrm{kg}$ males for the first quarter of the recovery-maintenance period, but not in females (data not shown). No definitive changes in abdominal fur appearance, incisor eruption, eye opening and testes descent or vaginal opening as well as reflex ontogeny parameters were detected in

Table 2. Organ weights after 18-day repeat dosing of 4-nitrophenol in newborn rats (main study).

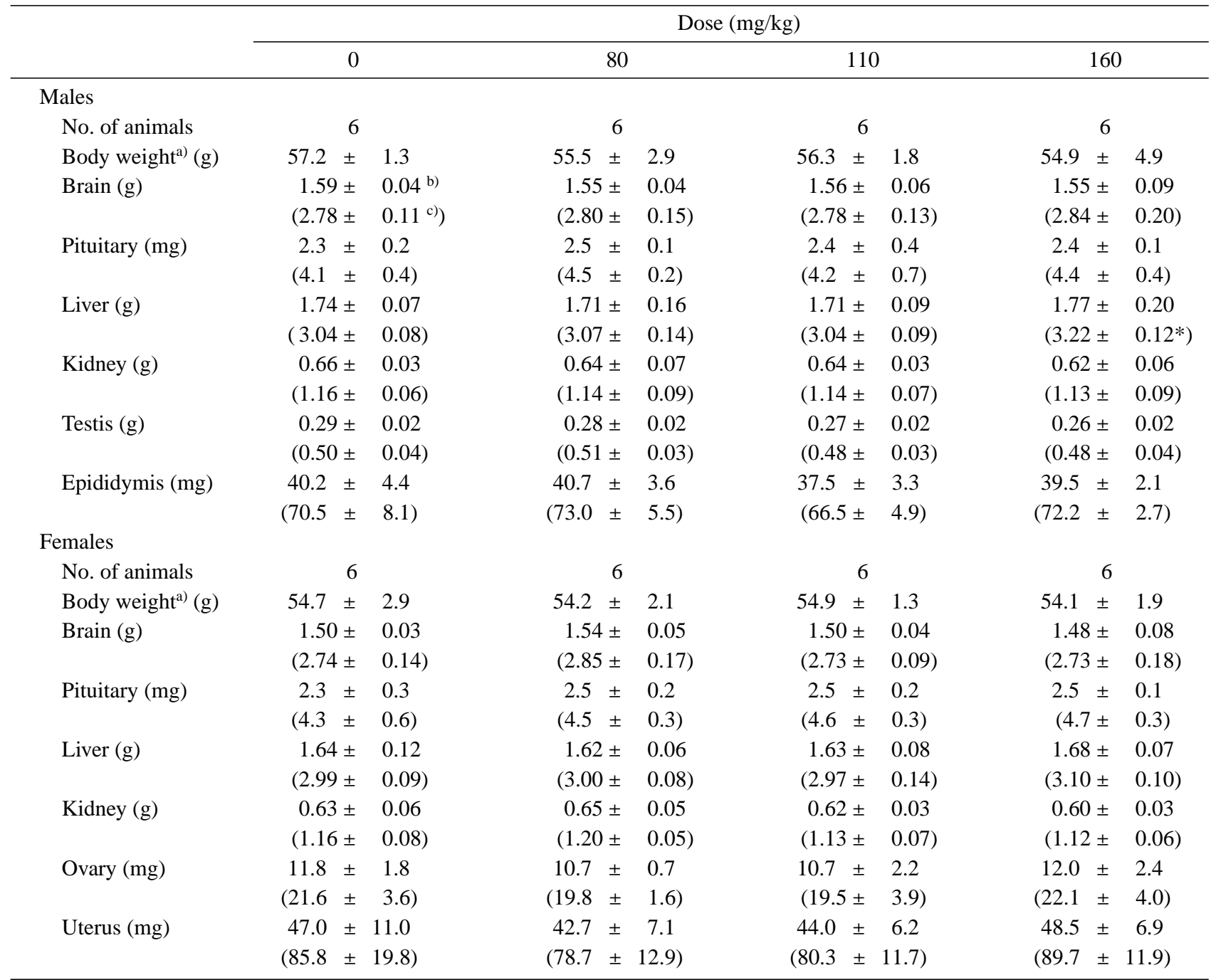

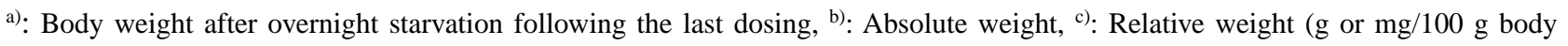
weight).

*: Significantly different from the control group $(\mathrm{p}<0.05)$. 
Comparative study of toxicity in newborn and young rats.

any dose groups (data not shown). There were significant changes in several absolute and relative organ weights in scheduled-sacrifice animals of both sexes at $20 \mathrm{mg} / \mathrm{kg}$ (Table 6), but these were no longer evident

Table 3. Clinical signs and mortality in the 28-day study of 4-nitrophenol in young rats.

\begin{tabular}{lcccc}
\hline & \multicolumn{5}{c}{ Dose $(\mathrm{mg} / \mathrm{kg})$} \\
\cline { 2 - 5 } Males & 60 & 160 & 400 & 1,000 \\
$\quad$ No. of animals & 12 & 12 & 12 & 12 \\
-Decrease in locomotor activity & - & - & - & 12 \\
-Oligopnea & - & - & - & 12 \\
-Prone/Lateral position & - & - & - & 10 \\
-Tonic convulsions & - & - & - & 3 \\
Deaths & - & - & - & 10 \\
Females & & & & \\
No. of animals & 12 & 12 & 12 & 12 \\
-Decrease in locomotor activity & - & - & - & 12 \\
-Oligopnea & - & - & - & 12 \\
-Prone/Lateral position & - & - & - & 10 \\
-Tonic convulsions & - & - & - & 4 \\
Deaths & - & - & - & 10 \\
\hline
\end{tabular}

- : No animals with the clinical sign.

Almost all of these clinical signs were observed just after the first dosing and disappeared within $2 \mathrm{hr}$. 7 male and 6 female rats died on the first dosing day and 3 males and 4 females died sporadically during the dosing period. after the recovery-maintenance period. The only significant change at $10 \mathrm{mg} / \mathrm{kg}$ was decreased absolute weights of testes. No chemical-related histopathological changes were noted in either scheduled-sacrifice and recovery-maintenance groups. Significant increase in $\mathrm{RBC}$ was observed in females receiving $20 \mathrm{mg} / \mathrm{kg}$ after the treatment but not after the recovery-maintenance period in the main study and in $\mathrm{RBC}, \mathrm{Hb}$ and $\mathrm{Ht}$ in both sexes at $30 \mathrm{mg} / \mathrm{kg}$ in the dose-finding study (data not shown). Although increases in serum GOT in males and total bilirubin in females were detected at 10 and $20 \mathrm{mg} / \mathrm{kg}$ after treatment, those were not consid-

Table 4. Histological findings in the kidneys of male rats after the dosing period in the 28-day study of 4-nitrophenol in young rats.

\begin{tabular}{lcccccc}
\hline & & \multicolumn{5}{c}{ Dose $(\mathrm{mg} / \mathrm{kg})$} \\
\cline { 3 - 7 } & Grade & 0 & 60 & 160 & 400 & 1,000 \\
\hline No. of animals & & 6 & 6 & 6 & 6 & $2^{\mathrm{a})}$ \\
Kidneys & & & & & & \\
-eosinophilic bodies & - & 3 & 4 & 5 & 0 & 0 \\
in proximal tubular cells & + & 3 & 1 & 1 & 3 & 0 \\
& ++ & 0 & 1 & 0 & 3 & 2 \\
Total observed number & & 3 & 2 & 1 & $6^{*}$ & 2 \\
\hline
\end{tabular}

- : No remarkable changes, $+:$ Slight, $++:$ Mild.

a): Only two of 12 male rats survived until the end of the dosing period.

*: Significantly different from the control group $(\mathrm{p}<0.05)$.

Table 5. Clinical signs and mortality in the repeated dose studies of 2,4-dinitrophenol in newborn rats.

\begin{tabular}{|c|c|c|c|c|c|c|}
\hline \multirow[b]{2}{*}{ Dose $(\mathrm{mg} / \mathrm{kg})$} & \multicolumn{3}{|c|}{ 18-day study (dose-finding study) } & \multicolumn{3}{|c|}{ 18-day study } \\
\hline & 3 & 10 & 30 & 3 & 10 & 20 \\
\hline \multicolumn{7}{|l|}{ Males } \\
\hline No. of animals & 5 & 5 & 5 & 12 & 12 & 12 \\
\hline -Decrease in locomotor activity & - & - & 3 & - & - & - \\
\hline -Panting & - & - & 2 & - & - & - \\
\hline -Prone position & - & - & - & - & - & - \\
\hline -Convulsions & - & - & 1 & - & - & - \\
\hline Deaths & - & - & 4 & - & - & - \\
\hline \multicolumn{7}{|l|}{ Females } \\
\hline No. of animals & 5 & 5 & 5 & 12 & 12 & 12 \\
\hline -Decrease in locomotor activity & - & - & 2 & - & - & - \\
\hline -Panting & - & - & 1 & - & - & - \\
\hline -Prone position & - & - & 1 & - & - & - \\
\hline -Convulsions & - & - & - & - & - & - \\
\hline Deaths & - & - & 1 & - & - & - \\
\hline
\end{tabular}

- : No animals with the clinical sign. 
ered to be chemical-induced because they were very slight and there was no dose-relationship (data not shown).

The unequivocally toxic level in newborn rats was concluded to be $30 \mathrm{mg} / \mathrm{kg} / \mathrm{day}$, as high lethality at this dose was shown in the dose-finding study but only lowered body and organ weights were observed at 20 $\mathrm{mg} / \mathrm{kg}$. The NOAEL is considered to be $10 \mathrm{mg} / \mathrm{kg} / \mathrm{day}$, at which only the lowering of absolute testis weights was observed.

\section{28-day study in young rats (including the dose- finding study)}

Clear toxic signs, such as decrease in locomotor activity, prone position, ptosis, panting, crawling position and salivation, were observed repeatedly during the dosing period at $80 \mathrm{mg} / \mathrm{kg}$ in both sexes, and 2 males and 6 females died, as shown in Table 7. However, decrease in locomotor activity and salivation in the $30 \mathrm{mg} / \mathrm{kg}$ group were mostly observed only after the first dosing. The relative liver weights were increased in both sexes of the $80 \mathrm{mg} / \mathrm{kg}$ scheduled-sacrifice group, and this persisted through the recovery period (data not shown). Relative organ weights for brain, kidneys and testes were increased only in 80 $\mathrm{mg} / \mathrm{kg}$ males. On histopathological examination (Table 8 ), mineralization of the corticomedullary junction in kidneys was observed in both sexes at $80 \mathrm{mg} / \mathrm{kg}$ in the scheduled-sacrifice and recovery groups, but the change was only statistically significant in males of the scheduled-sacrifice group. On hematological examination, increase in $\mathrm{Hb}$ and $\mathrm{Ht}$ during the treatment, and decrease in $\mathrm{RBC}, \mathrm{Hb}$ and $\mathrm{Ht}$ in the recovery period were observed, limited to $80 \mathrm{mg} / \mathrm{kg}$ males (data not shown). Although blood chlorine levels were slightly decreased in 30 and $80 \mathrm{mg} / \mathrm{kg}$ males and total bilirubin was slightly increased in females receiving $10 \mathrm{mg} / \mathrm{kg}$ and more (data not shown), no changes in histopathology or organ weights were observed at $30 \mathrm{mg} / \mathrm{kg}$ or lower. In the dose-finding study, no significant changes were apparent except for a prone position of a few animals given $60 \mathrm{mg} / \mathrm{kg}$ during the early dosing period (Table 7).

As an unequivocally toxic level, $80 \mathrm{mg} / \mathrm{kg} /$ day is appropriate, based on the clear toxic signs with deaths at $80 \mathrm{mg} / \mathrm{kg}$ and the slight effects at $60 \mathrm{mg} / \mathrm{kg}$ in the dose-finding study. The NOAEL is presumed to be 20 $\mathrm{mg} / \mathrm{kg} /$ day from the dose-finding study because adverse effects at $30 \mathrm{mg} / \mathrm{kg}$ were mostly observed only after the first dosing in the main study even though the exposure period of the dose-finding study was shorter than the main study.
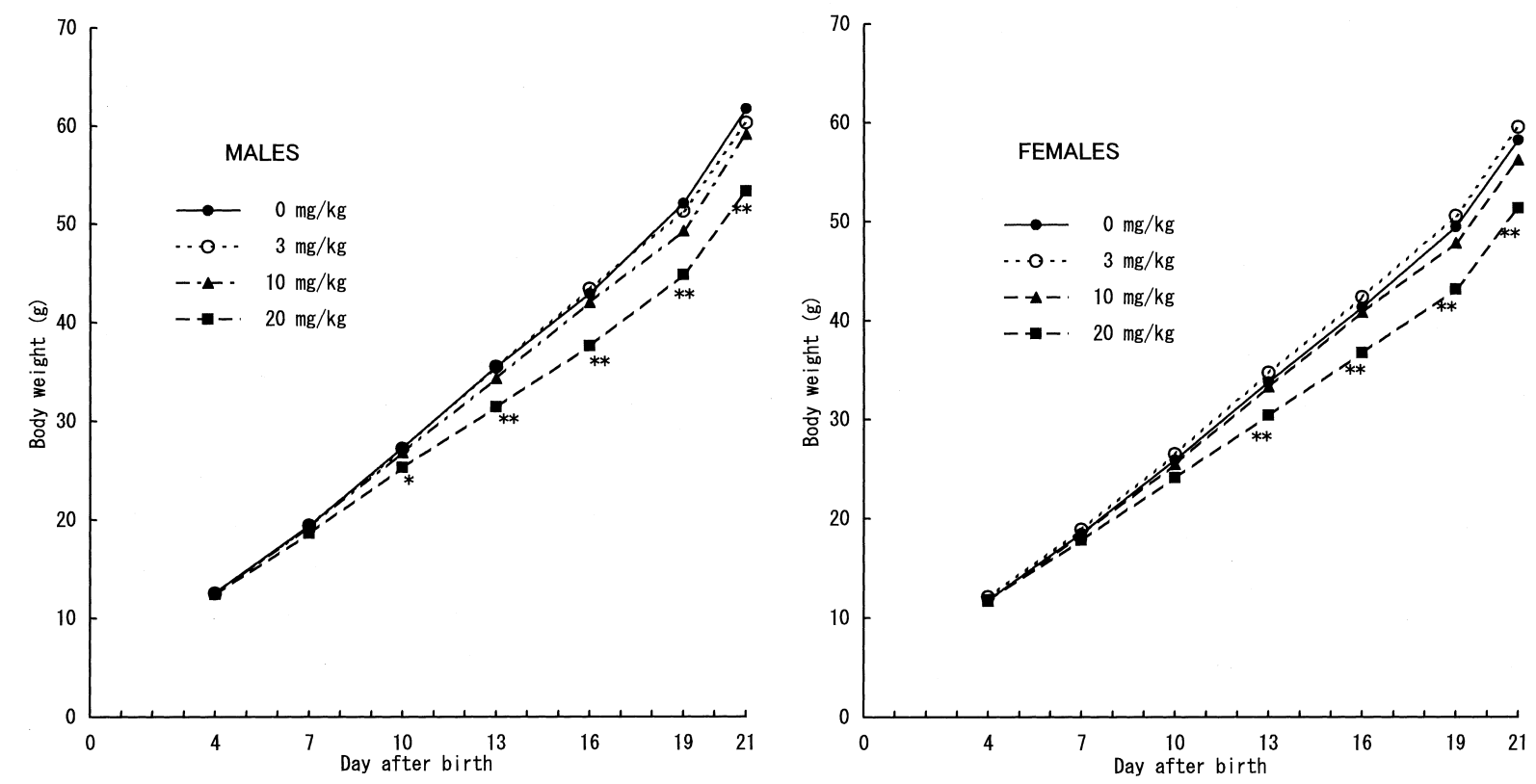

Fig. 2. Body weight change during the dosing period in the 18-day study of 2,4-dinitrophenol in newborn rats. $*$, **: Significantly different from the controls $(\mathrm{p}<0.05, \mathrm{p}<0.01)$. 
Comparative study of toxicity in newborn and young rats.

\section{DISCUSSION}

Several investigations of chemical exposure of perinatal animals through their dams have been reported, but only a few studies have been conducted with direct administration to newborn animals. Unfortunately, detailed analyses of general toxicity have not hitherto been performed in the latter cases. During the newborn period, the infants may orally intake chemicals not only through their mothers' milk but also by mouthing of pacifiers, plastic goods, etc. or eating baby foods containing pollutant chemicals. The present study was therefore conducted to allow comparison of the results for newborn and young rats under the same experimental conditions. For toxicity/safety regulation in general, an NOAEL must first be established, then the acceptable daily intake (ADI) or tolerable daily intake (TDI) is derived using uncertainty factors. However, the NOAEL does not indicate the precise toxic potential because it is directly derived from doses used in toxici-

Table 6. Organ weights after the dosing period in the 18-day study of 2,4-dinitrophenol in newborn rats.

\begin{tabular}{|c|c|c|c|c|c|c|c|c|}
\hline \multirow{2}{*}{ Males } & \multicolumn{8}{|c|}{ Dose $(\mathrm{mg} / \mathrm{kg})$} \\
\hline & \multicolumn{2}{|c|}{0} & \multicolumn{2}{|c|}{3} & \multicolumn{2}{|c|}{10} & \multicolumn{2}{|c|}{20} \\
\hline No. of animals & \multicolumn{2}{|c|}{6} & \multicolumn{2}{|c|}{6} & \multicolumn{2}{|c|}{6} & \multicolumn{2}{|c|}{6} \\
\hline Body weight $^{\mathrm{a})}(\mathrm{g})$ & $56.6 \pm$ & 3.6 & $54.2 \pm$ & 3.2 & $53.0 \pm$ & 3.7 & $48.6 \pm$ & $5.5 * *$ \\
\hline Brain $(\mathrm{g})$ & $\begin{array}{r}1.50 \pm \\
(2.66 \pm\end{array}$ & $\begin{array}{l}0.03^{\mathrm{b})} \\
\left.0.18^{\mathrm{c})}\right)\end{array}$ & $\begin{array}{r}1.52 \pm \\
(2.82 \pm\end{array}$ & $\begin{array}{l}0.06 \\
0.14)\end{array}$ & $\begin{array}{r}1.54 \pm \\
(2.93 \pm\end{array}$ & $\begin{array}{l}0.06 \\
0.25)\end{array}$ & $\begin{array}{r}1.47 \pm \\
(3.06 \pm\end{array}$ & $\begin{array}{l}0.07 \\
0.33)\end{array}$ \\
\hline Pituitary (mg) & $\begin{array}{r}3.1 \pm \\
(5.5 \pm\end{array}$ & $\begin{array}{l}0.2 \\
0.2)\end{array}$ & $\begin{array}{r}3.1 \pm \\
(5.6 \pm\end{array}$ & $\begin{array}{l}0.1 \\
0.2)\end{array}$ & $\begin{array}{r}3.0 \pm \\
(5.6 \pm\end{array}$ & $\begin{array}{l}0.3 \\
0.3)\end{array}$ & $\begin{array}{r}2.6 \pm \\
(5.5 \pm\end{array}$ & $\begin{array}{l}0.3 * * \\
0.5)\end{array}$ \\
\hline Liver $(\mathrm{g})$ & $\begin{array}{r}1.85 \pm \\
(3.25 \pm\end{array}$ & $\begin{array}{l}0.16 \\
0.13)\end{array}$ & $\begin{array}{r}1.71 \pm \\
(3.16 \pm\end{array}$ & $\begin{array}{l}0.10 \\
0.07)\end{array}$ & $\begin{array}{r}1.73 \pm \\
(3.26 \pm\end{array}$ & $\begin{array}{l}0.17 \\
0.14)\end{array}$ & $\begin{array}{r}1.61 \pm \\
(3.30 \pm\end{array}$ & $\begin{array}{l}0.21 \\
0.11)\end{array}$ \\
\hline Kidney (g) & $\begin{array}{r}0.66 \pm \\
(1.16 \pm\end{array}$ & $\begin{array}{l}0.06 \\
0.08)\end{array}$ & $\begin{array}{r}0.66 \pm \\
(1.23 \pm\end{array}$ & $\begin{array}{l}0.05 \\
0.08)\end{array}$ & $\begin{array}{r}0.66 \pm \\
(1.24 \pm\end{array}$ & $\begin{array}{l}0.05 \\
0.08)\end{array}$ & $\begin{array}{r}0.61 \pm \\
(1.26 \pm\end{array}$ & $\begin{array}{l}0.08 \\
0.07)\end{array}$ \\
\hline Testis (g) & $\begin{array}{r}0.31 \pm \\
(0.05 \pm\end{array}$ & $\begin{array}{l}0.03 \\
0.04)\end{array}$ & $\begin{array}{r}0.29 \pm \\
(0.53 \pm\end{array}$ & $\begin{array}{l}=0.01 \\
=\quad 0.03)\end{array}$ & $\begin{array}{r}0.27 \pm \\
(0.51 \pm\end{array}$ & $\begin{array}{l}0.01 * \\
0.04)\end{array}$ & $\begin{array}{r}0.26 \pm \\
(0.54 \pm\end{array}$ & $\begin{array}{l}0.04 * \\
0.05)\end{array}$ \\
\hline Prostate (mg) & $\begin{array}{r}82.6 \pm \\
(146.1 \pm\end{array}$ & $\begin{array}{l}12.2 \\
20.2)\end{array}$ & $\begin{array}{r}79.9 \pm \\
(148.3 \pm\end{array}$ & $\begin{array}{l}13.7 \\
=28.7)\end{array}$ & $\begin{array}{r}81.4 \pm \\
(154.3 \pm\end{array}$ & $\begin{array}{c}7.7 \\
19.1)\end{array}$ & $\begin{array}{r}76.4 \pm \\
(158.3 \pm\end{array}$ & $\begin{array}{l}13.6 \\
29.5)\end{array}$ \\
\hline Epididymis (mg) & $\begin{array}{r}50.8 \pm \\
(89.7\end{array}$ & $\begin{array}{l}5.1 \\
6.0)\end{array}$ & $\begin{array}{r}55.5 \pm \\
(103.1 \pm\end{array}$ & $=\begin{array}{c}6.4 \\
15.9)\end{array}$ & $\begin{array}{r}47.0 \pm \\
(89.3 \pm\end{array}$ & $\begin{array}{c}2.9 \\
11.2)\end{array}$ & $\begin{array}{r}48.2 \pm \\
(99.6 \pm\end{array}$ & $\begin{array}{l}4.6 \\
9.0)\end{array}$ \\
\hline \multicolumn{9}{|l|}{ Females } \\
\hline No. of animals & \multicolumn{2}{|c|}{6} & \multicolumn{2}{|c|}{6} & \multicolumn{2}{|c|}{6} & \multicolumn{2}{|c|}{6} \\
\hline Body weight $^{\mathrm{a}}$ (g) & $52.7 \pm$ & 2.8 & $53.5 \pm$ & 3.8 & $50.1 \pm$ & 3.9 & $45.5 \pm$ & $3.4 * *$ \\
\hline Brain $(\mathrm{g})$ & $\begin{array}{r}1.47 \pm \\
(2.80 \pm\end{array}$ & $\begin{array}{l}0.05 \\
0.20)\end{array}$ & $\begin{array}{r}1.47 \pm \\
(2.75 \pm\end{array}$ & $\begin{array}{l}0.05 \\
0.17)\end{array}$ & $\begin{array}{r}1.50 \pm \\
(3.00 \pm\end{array}$ & $\begin{array}{l}0.04 \\
0.22)\end{array}$ & $\begin{array}{r}1.43 \pm \\
(3.14 \pm\end{array}$ & $\begin{array}{l}0.04 \\
0.23 *)\end{array}$ \\
\hline Pituitary (mg) & $\begin{array}{r}3.1 \pm \\
5.9 \pm\end{array}$ & $\begin{array}{l}0.1 \\
0.4)\end{array}$ & $\begin{array}{r}3.1 \pm \\
(5.9 \pm\end{array}$ & $\begin{array}{l}0.3 \\
0.4)\end{array}$ & $\begin{array}{c}3.1 \pm \\
6.2 \pm\end{array}$ & $\begin{array}{l}0.3 \\
0.5)\end{array}$ & $\begin{array}{r}2.9 \pm \\
6.4 \pm\end{array}$ & $\begin{array}{l}0.2 \\
0.4)\end{array}$ \\
\hline Liver $(\mathrm{g})$ & $\begin{array}{r}1.69 \pm \\
(3.21 \pm\end{array}$ & $\begin{array}{l}0.12 \\
0.21)\end{array}$ & $\begin{array}{r}1.74 \pm \\
(3.24 \pm\end{array}$ & $\begin{array}{l}0.15 \\
0.13)\end{array}$ & $\begin{array}{r}1.61 \pm \\
(3.20 \pm\end{array}$ & $\begin{array}{l}0.19 \\
0.16)\end{array}$ & $\begin{array}{r}1.53 \pm \\
(3.36 \pm\end{array}$ & $\begin{array}{l}0.11 \\
0.16)\end{array}$ \\
\hline Kidney (g) & $\begin{array}{r}0.63 \pm \\
(1.19 \pm\end{array}$ & $\begin{array}{l}0.05 \\
0.05)\end{array}$ & $\begin{array}{r}0.68 \pm \\
(1.26 \pm\end{array}$ & $\begin{array}{l}0.05 \\
0.06)\end{array}$ & $\begin{array}{r}0.63 \pm \\
(1.26 \pm\end{array}$ & $\begin{array}{l}0.06 \\
0.05)\end{array}$ & $\begin{array}{r}0.60 \pm \\
(1.32 \pm\end{array}$ & $\begin{array}{l}0.02 \\
0.08 * *)\end{array}$ \\
\hline Ovary (mg) & $\begin{array}{r}14.1 \pm \\
(27.0 \pm\end{array}$ & $\begin{array}{l}2.7 \\
5.8)\end{array}$ & $\begin{array}{r}14.4 \pm \\
(26.9 \pm\end{array}$ & $\begin{array}{l}1.8 \\
3.3)\end{array}$ & $\begin{array}{r}14.4 \pm \\
(28.7\end{array}$ & $\begin{array}{l}2.0 \\
3.4)\end{array}$ & $\begin{array}{r}12.2 \pm \\
(26.9 \pm\end{array}$ & $\begin{array}{l}2.9 \\
6.3)\end{array}$ \\
\hline Uterus (mg) & $\begin{array}{r}48.1 \pm \\
(91.2 \pm\end{array}$ & $\begin{array}{c}9.0 \\
16.0)\end{array}$ & $\begin{array}{r}47.8 \pm \\
(89.8 \pm\end{array}$ & $\begin{array}{c}=9.0 \\
=26.6)\end{array}$ & $\begin{array}{c}36.0 \pm \\
(71.9 \pm\end{array}$ & $\begin{array}{l}4.7 \\
=7.2)\end{array}$ & $\begin{array}{r}44.6 \pm \\
(98.9 \pm\end{array}$ & $\begin{array}{c}4.9 \\
16.2)\end{array}$ \\
\hline
\end{tabular}

a): Body weight after overnight starvation following the last dosing, ${ }^{\text {b): }}$ Absolute weight, ${ }^{\text {c) }}$ : Relative weight $(\mathrm{g}$ or mg/100 $\mathrm{g}$ body weight).

*, **: Significantly different from the control group $(\mathrm{p}<0.05, \mathrm{p}<0.01)$. 
ty studies. Therefore, we estimated appropriate NOAELs based on both the dose-finding study and main study, and compared these values. Secondly, we estimated appropriate unequivocally toxic levels from both animal studies and compared them in addition. In this study, these were established as doses inducing severe toxic signs, including death or critical histopathological damage.

Symptoms of the toxicity of 4NP generally include hyperthermia, respiratory depression, methemoglobinemia, CNS depression, and central and peripheral vagal stimulation (Beard and Noe, 1981). As for repeated dose oral toxicity, only a 13-week rat gavage study conducted in Hazleton (1989), not yet published, is described in Toxicological Profiles (ATSDR, 1991). However, early death at $40 \mathrm{mg} / \mathrm{kg}$ in the Hazleton study was not confirmed by our young rat study (no lethality at $400 \mathrm{mg} / \mathrm{kg}$ ), and we are not able to speculate on the reason for this big dose difference in lethali- ty because of a lack of detailed information about the Hazleton study. ATSDR (1991) also described no severe tissue damage by $4 \mathrm{NP}$ in most studies with any exposure route, the results being consistent with our investigation, but the reports did not include newborn toxicity data. Therefore the present study is the first to look into newborn toxicity of 4NP. The unequivocally toxic levels were estimated to be $230 \mathrm{mg} / \mathrm{kg} / \mathrm{day}$ in newborn rats and 600 to $800 \mathrm{mg} / \mathrm{kg} /$ day in young rats, and NOAELs to be $110 \mathrm{mg} / \mathrm{kg} /$ day in newborn rats and $400 \mathrm{mg} / \mathrm{kg} /$ day in young rats. Based on these estimations, newborn rats are 2.5 to 4 times more susceptible to this chemical than young rats, as shown in Table 9.

Since DNP was used extensively in diet pills during the 1930s, various effects in humans likely due to oxidative phosphorylation uncoupling effects, such as death, hyperthermia, excessive perspiration, elevated respiration and pulse rate and body weight loss are described in Toxicological Profiles (ATSDR, 1995).

Table 7. Clinical signs and mortality in repeated dose studies of 2,4-dinitrophenol in young rats.

\begin{tabular}{|c|c|c|c|c|c|c|c|c|c|}
\hline \multirow[b]{2}{*}{ Dose (mg/kg) } & \multicolumn{5}{|c|}{ 14-day study (dose-finding study) } & \multicolumn{4}{|c|}{ 28-day study } \\
\hline & 0.6 & 2 & 6 & 20 & 60 & 3 & 10 & 30 & 80 \\
\hline \multicolumn{10}{|l|}{ Males } \\
\hline No. of animals & 4 & 4 & 4 & 4 & 4 & 6 & 6 & 12 & 12 \\
\hline -Decrease in locomotor activity & - & - & - & - & - & - & - & $6^{\mathrm{b})}$ & $12^{\mathrm{c})}$ \\
\hline -Prone position & - & - & - & - & $2^{\text {a) }}$ & - & - & - & $12^{c)}$ \\
\hline -Ptosis & - & - & - & - & - & - & - & - & $12^{c)}$ \\
\hline -Panting & - & - & - & - & - & - & - & - & $12^{\mathrm{c})}$ \\
\hline -Crawling position & - & - & - & - & - & - & - & - & $12^{\mathrm{c})}$ \\
\hline -Salivation & - & - & - & - & - & - & - & $2^{\text {b) }}$ & $12^{\mathrm{c})}$ \\
\hline -Tonic convulsions & - & - & - & - & - & - & - & - & 2 \\
\hline -Rigidity & - & - & - & - & - & - & - & - & 2 \\
\hline Death & - & - & - & - & - & - & - & - & 2 \\
\hline \multicolumn{10}{|l|}{ Females } \\
\hline No. of animals & 4 & 4 & 4 & 4 & 4 & 6 & 6 & 12 & 12 \\
\hline -Decrease in locomotor activity & - & - & - & - & - & - & - & $5^{\text {b) }}$ & $12^{\mathrm{c})}$ \\
\hline -Prone position & - & - & - & - & $1^{\text {a) }}$ & - & - & - & $12^{\mathrm{c})}$ \\
\hline -Ptosis & - & - & - & - & - & - & - & - & $12^{\mathrm{c})}$ \\
\hline -Panting & - & - & - & - & - & - & - & - & $12^{\mathrm{c})}$ \\
\hline -Crawling position & - & - & - & - & - & - & - & - & $12^{\mathrm{c})}$ \\
\hline -Salivation & - & - & - & - & - & - & - & $1^{\mathrm{b})}$ & $12^{\mathrm{c})}$ \\
\hline -Tonic convulsions & - & - & - & - & - & - & - & - & 4 \\
\hline -Rigidity & - & - & - & - & - & - & - & - & 5 \\
\hline Death & - & - & - & - & - & - & - & - & 6 \\
\hline
\end{tabular}

- : No animals with the clinical sign.

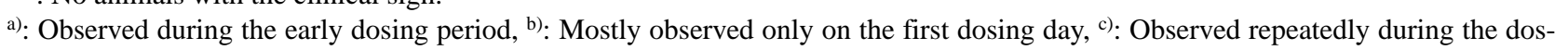
ing period. 
Comparative study of toxicity in newborn and young rats.

Many animal studies with oral administration were also conducted, but mostly in the 1930s and 1940s, and no toxicity study in infants has been reported. The present study provides the newest reliable data, with toxicity level and toxic profile in line with those of the old studies. The unequivocally toxic effect levels were estimated to be 30 and $80 \mathrm{mg} / \mathrm{kg} / \mathrm{day}$, and NOAELs to be 10 and $20 \mathrm{mg} / \mathrm{kg} /$ day in newborn and young rats, respectively. The differences in sensitivity between newborn and young rats range from 2 to 3 times (Table 9).

As neither chemical-induced clear histopathological changes or would be expected to accumulate in the body, based on metabolic experiments (Robinson et al., 1951; Tremaine et al., 1984; Robert and Hagardorn, 1985), any toxicity, including mortality, must be the result of pharmacological actions. Therefore, the toxicity differences between newborn and young rats would be due to variation in metabolic rate including elimination and toxicodynamics. However, there is no supporting information for this speculation in the literature.

This is the first systematic study to look into the direct effects of chemicals in newborn to weaning animals and also delayed responses without further treatment up to young adult ages. Neither chemical exerted

Table 8. Histological findings in the 28-day study of 2,4-dinitrophenol in young rats.

\begin{tabular}{|c|c|c|c|c|c|c|c|c|c|}
\hline \multirow[b]{2}{*}{ Dose $(\mathrm{mg} / \mathrm{kg})$} & \multirow[b]{2}{*}{ Grade } & \multicolumn{5}{|c|}{ Scheduled-sacrificed group } & \multicolumn{3}{|c|}{ Recovery group } \\
\hline & & 0 & 3 & 10 & 30 & 80 & 0 & 30 & 80 \\
\hline \multicolumn{10}{|l|}{ Males } \\
\hline No. of animals & & 6 & 6 & 6 & 6 & $4^{\text {a) }}$ & 6 & 6 & 6 \\
\hline \multicolumn{10}{|l|}{ Kidneys } \\
\hline - Mineralization, & - & 6 & 6 & 6 & 6 & 1 & 6 & 6 & 4 \\
\hline \multirow[t]{2}{*}{ corticomedullary junction } & + & 0 & 0 & 0 & 0 & 1 & 0 & 0 & 2 \\
\hline & ++ & 0 & 0 & 0 & 0 & 2 & 0 & 0 & 0 \\
\hline Total observed number & & 0 & 0 & 0 & 0 & $3^{*}$ & 0 & 0 & 2 \\
\hline \multicolumn{10}{|l|}{ Females } \\
\hline No. of animals & & 6 & 6 & 6 & 6 & $3^{\mathrm{b})}$ & 6 & 6 & $3^{\text {b) }}$ \\
\hline \multicolumn{10}{|l|}{ Kidneys } \\
\hline - Mineralization, & - & 6 & 6 & 6 & 6 & 1 & 6 & 6 & 1 \\
\hline \multirow[t]{2}{*}{ corticomedullary junction } & + & 0 & 0 & 0 & 0 & 2 & 0 & 0 & 2 \\
\hline & ++ & 0 & 0 & 0 & 0 & 0 & 0 & 0 & 0 \\
\hline Total observed number & & 0 & 0 & 0 & 0 & 2 & 0 & 0 & 2 \\
\hline
\end{tabular}

- : No remarkable changes, + : Slight, + + : Mild.

a): $2 / 6$ male rats in scheduled-sacrificed group died during dosing the period, b): Each $3 / 6$ female rats in scheduled-sacrificed group and recovery group died during the dosing period.

*: Significantly different from the control group $(p<0.05)$.

Table 9. Comparison of unequivocally toxic levels and NOAELs in newborn and young rats.

\begin{tabular}{lcc}
\hline & Level (mg/kg/day) & Ratio (young/newborn) \\
\hline 4-Nitrophenol & 230 & $2.6-3.5$ \\
Unequivocally toxic level (newborn) & $600-800$ & 3.6 \\
Unequivocally toxic level (young) & 110 & \\
NOAEL (newborn) & 400 & 2.7 \\
NOAEL (young) & 30 & 2.0 \\
2,4-Dinitrophenol & 80 & \\
Unequivocally toxic level (newborn) & 10 & \\
Unequivocally toxic level (young) & 20 & \\
NOAEL (newborn) & & \\
NOAEL (young) & & \\
\hline
\end{tabular}


any developmental toxicity in the newborn in terms of external development and reflex ontogeny. This result clearly indicates that there is no infant specific toxicity with the two chemicals.

In the pesticide program by US EPA (1999), the counsel group recommended use of an additional uncertainty factor of 10 for the ADI for infant safety in the absence of specific data for developmental toxicity, following the recommendations of the NRC (1993), Schilter et al. (1996) and Dourson et al. (1996). For example, an additional uncertainty factor of 10 was applied to Thiamethoxam, on condition that the additional uncertainty factor would be removed when infant safety was confirmed (Fed Reg, 2000). The results of the present studies seem to support the conclusion that this additional uncertainty factor is appropriate for assessing infant safety.

In Japan, more than 300 toxicity studies, including 28-day repeated dose toxicity studies in young rats and OECD combined repeated dose and reproductive /developmental toxicity screening tests [OECD TG 422] in young adult rats, have been conducted in the existing chemical testing program since 1980. Approximately 500 of the 28-day repeated dose studies in young animals for new industrial chemicals have also been conducted as screening tests in the Japanese Chemical Control Act and the results were submitted to the Japanese Government from the chemical industry. These abundant repeated dose toxicity data for young and young adult animals will become more valuable when the appropriate safety factors for infants are established for general application with full analysis of our series of studies.

\section{ACKNOWLEDGMENT}

The authors gratefully acknowledge the financial support of the Office of Chemical Safety, Pharmaceutical and Medical Safety Bureau, Ministry of Health, Labor and Welfare, Japan.

\section{REFERENCES}

ATSDR (1991) Toxicological profile for nitrophenols: 2-nitrophenol and 4-nitrophenol, ed. by Agency for Toxic Substances and Disease Registry, published by US Department of Health \& Human Services, Public Health Service.

ATSDR (1995) Toxicological profile for dinitrophenols, ed. by Agency for Toxic Substances and Disease Registry, published by US Department of
Health \& Human Services, Public Health Service.

Bartlett, M.S. (1937): Properties of sufficiency and statistical tests. Proc. Roy. Soc., A160, 268-282.

Beard, R.R. and Noe, J.T. (1981): Aromatic nitro and amino compounds. In Patty's Industrial Hygiene and Toxicology (Clayton, G.D. and Clayton, F.E., eds), Vol.2A, pp. 2426-2427, Interscience Publishers, New York.

Bullock, B.C., Newbold, R.R. and McLachlan, J.A. (1988): Lesions of testis and epididymis associated with prenatal diethylstilbestrol exposure. Environ. Health Perspect., 77, 29-31.

Dourson, M.L., Felter, S.P. and Robinson, D. (1996): Evolution of science-based uncertainty factors in noncancer risk assessment. Regul. Toxicol. Pharmacol., 24, 108-120.

Dunnett, C.W. (1964): New tables for multiple comparisons with a control. Biometrics, 20, 482-491.

Fed Reg (2000) Thiamethoxam; Pesticide tolerances for emergency exemptions. In Federal Register, US. Vol. 65 No. 245, pp. 79755-79762.

Fisher, R.A. (1973): Statistical Methods of Research Workers. Fourteenth edition, p.6. Hapner Publishing Company, New York, USA.

Gray, L.E. Jr., Ostby, J.S. and Kelce, W.R. (1994): Developmental effects of an environmental antiandrogen: The fungicide vinclozolin alters sex differentiation of the male rat. Toxicol. Appl. Pharmacol., 129, 46-52.

Gray, L.E., Ostby, J.S. and Kelce, W.R. (1997a): A dose-response analysis of the reproductive effects of a single gestational dose of 2,3,7,8-tetrachlorodibenzo- $p$-dioxin in male Long Evans Hooded rat offspring. Toxicol. Appl. Pharmacol., 146, 11-20.

Gray, L.E., Wolf, C., Mann, P. and Ostby, J.S. (1997b): In utero exposure to low doses of 2,3,7,8-tetrachlorodibenzo- $p$-dioxin alters reproductive development of female Long Evans hooded rat offspring. Toxicol. Appl. Pharmacol., 146, 237-244.

Hollander, M. and Wolfe, D.A. (1973): Nonparametric Statistical Methods. John Wiley and Sons, New York.

Katsuda, S., Yoshida, M., Watanabe, G., Taya, K. and Maekawa, A. (2000): Irreversible effects of neonatal exposure to $p$-tert-octylphenol on the reproductive tract in female rats. Toxicol. Appl. Pharmacol., 165, 217-226.

Khan, S.A., Ball, R.B. and Hendry, W.J., 3rd. (1998): Effects of neonatal administration of diethylstilbestrol in male hamsters: Disruption of reproductive 
Comparative study of toxicity in newborn and young rats.

function in adults after apparently normal pubertal development. Biol. Reprod., 58, 137-142.

Kruskal, W.H. and Wallis, W.A. (1952): Use of ranks in one-criterion variance analysis. J. Am. Statist. Assoc., 47, 583-621.

Lee, P.C. (1998): Disruption of male reproductive tract development by administration of the xenoestrogen, nonylphenol, to male newborn rats. Endocrine, 9, 105-111.

Mann, H.B. and Whiteny, D.R. (1947): On a test of whether one of two random variables is stochastically larger than the other. Ann. Math. Stat., 18, 50-60.

MHLW (2001a) p-Nitrophenol sodium salt (824-78-2). In Toxicity Testing Reports of Environmental Chemicals (Ministry of Health, Labor and Welfare ed.), Vol. 8, pp. 809-836, Chemicals Investigation Promoting Council, Japan.

MHLW (2001b) 2,4-Dinitrophenol (51-28-5). In Toxicity Testing Reports of Environmental Chemicals (Ministry of Health, Labor and Welfare ed.), Vol. 8, pp. 7-36, Chemicals Investigation Promoting Council, Japan.

Mylchreest, E., Cattley, R.C. and Foster, P.M. (1998): Male reproductive tract malformations in rats following gestational and lactational exposure to di(n-butyl) phthalate: An antiandrogenic mechanism? Toxicol. Sci., 43, 47-60.

NRC (National Research Council) (1993) Pesticides in the diets of infants and children. National Academy Press, Washington, DC.

Robert, T.A. and Hagardorn, A.N. (1985): Plasma lev- els and kinetic disposition of 2,4-dinitrophenol and its metabolites 2-amino-4-nitrophenol and 4amino-2-nitrophenol in the mouse. J. Chromatogr., 45, 177-186.

Robinson, D., Smith, J.N. and Williams, R.T. (1951): Studies in detoxication. 39. Nitro compounds (a) the metabolism of $\mathrm{o}^{-}, \mathrm{m}-$, and $p$-nitrophenols in the rabbit; (b) the glucuronides of the mononitrophenols and observations on the anomalous optical rotations of triacetyl $\beta$-0-nitrophenylglucuronide and its methyl ester. Biochem. J., 50, 221-227.

Scheffe, H. (1953): A method for judging all contrasts in the analysis of variance. Biometrika, 40, 87104.

Schilter, B., Renwick, A.G. and Huggett, A.C. (1996): Limits for pesticide residues in infant food: A safety-based approach. Regul. Toxicol. Pharmacol., 24, 126-140.

Tremaine, L.M., Diamond, G.L. and Quebbemann, A.J. (1984): In vivo quantification of renal glucuronide and sulfate conjugation of 1-naphthol and $p$-nitrophenol in the rat., Biochem. Pharmacol., 33, 419427.

US EPA (1999) Toxicology data requirements for assessing risks of pesticide exposure to children's heath (Draft). Report of the Toxicology Working Group of the 10X Task Force. Office of Pesticide Programs. Washington: U.S. Environmental Protection Agency. (See: http://www.epa.gov /scipoly/sap/1999/may/10xtx428.pdf; as of 28 April 1999). 